\title{
Studi Korelasi Aktivitas Listrik Udara sebagai Prekursor Kejadian Gempabumi di Pidie Jaya
}

\author{
Abdi Jihad, ${ }^{1, *}$ Lori Agung Satria, ${ }^{2}$ Vrieslend H Banyunegoro, ${ }^{1}$ Muhajir, ${ }^{3}$ dan Nasyithah Az-Zahra Lubis ${ }^{4}$ \\ ${ }^{1}$ Badan Meteorologi, Klimatologi, dan Geofisika, Stasiun Geofisika Mata Ie Banda Aceh, Jl. Raya Mata Ie Banda Aceh, 23352 \\ ${ }^{2}$ Badan Meteorologi, Klimatologi, dan Geofisika, Stasiun Geofisika Silaing Bawah, \\ Jl. Sultan Syahrir Silaing Bawah, Padang Panjang, Sumatera Barat 27118 \\ ${ }^{3}$ Badan Meteorologi, Klimatologi, dan Geofisika, Stasiun Klimatologi Indrapuri \\ Jl. Banda Aceh Medan Km 27,Indrapuri, Aceh Besar, 23363 \\ ${ }^{4}$ Badan Meteorologi, Klimatologi, dan Geofisika, Stasiun Meteorologi Sultan Iskandar Muda, \\ Bandara Sultan Iskandar Muda Blang Bintang, Banda Aceh 23372
}

Intisari

\begin{abstract}
Gempabumi menjadi salah satu fenomena alam yang terus menjadi topik kajian menarik untuk dikaji. Kajian mengenai tanda-tanda sebelum terjadinya gempabumi merupakan topik yang telah lama dikaji. Tujuan penelitian ini dilakukan untuk mengetahui hubungan antara kejadian gempabumi Pidie Jaya dengan aktivitas listrik udara. Data penelitian terdiri dari data aktivitas listrik udara yang dikumpulkan menggunakan LD2000, data citra satelit Himawari8 dan data curah hujan dari model GSMaP. Hubungan antara listrik udara dan gempabumi dianalisis dengan menghitung koefisien korelasi antara kedua variabel tersebut. Hasilnya, diketahui adanya peningkatan aktivitas listrik udara H-2 sebelum terjadinya gempabumi. Kesimpulan bahwa peningkatan aktivitas listrik udara menjadi tanda-tanda sebelum gempabumi didasari pada hasil korelasi antara listrik udara dan curah hujan yang bernilai negatif. Hal ini menunjukan hubungan lemah antara peningkatan aktivitas listrik udara dengan curah hujan. Sebagaimana umumnya kejadian listrik udara yang diakibatkan awan-awan konvektif dengan diikuti oleh aktivitas hujan dengan intensitas sedang hingga tinggi.
\end{abstract}

\begin{abstract}
Earthquake is a natural phenomenon that becomes an interesting topic to be studied. Precursors of an earthquake is a topic that had been long studied. This research aims to understand the relationship between Pidie Jaya earthquake and the electrical activity of the air. The data needed to conduct this research are electrical activity in the air that captured by LD2000, Himawari8 satellite data, and rainfall data obtained from GSMaP model. That relationship is obtained by calculating the correlation coefficient between those variables. The result shows that there is an increased in electrical activity two days before the event occurred. In order to reach the conclusion, the relationship between electrical activity in the air and rainfall correlation is calculated and it shows a negative value. This value means that there is a weak correlation between electrical activity in the air and rainfall. This weak correlation does not show up in the correlation between high rainfall and convective clouds growth.
\end{abstract}

Keywords: correlation; lightning; Himawari8; GSMap; Convective Clouds.

http://dx.doi.org/10.12962/j24604682.v15i1.4285

2460-4682 @Departemen Fisika, Fakultas Sains-ITS

\section{PENDAHULUAN}

Gempabumi merupakan fenomena alam yang terjadi akibat terlepasnya energi pada proses interaksi lempeng tektonik. Tidak sedikit dari kejadian gempabumi mengakibatkan kerugian jiwa dan harta. Gempabumi menjadi salah satu fenomena alam yang terus dikaji untuk memperoleh informasi tentang tanda-tanda sebelum kejadian gempabumi. Studi mengenai

\footnotetext{
*Electronic address: abdijihad.bmkg@gmail.com
}

tanda-tanda sebelum kejadian gempabumi telah dilakukan sejak tahun 1930-an, namun proses secara detil yang mendasari fenomena tersebut masih belum di pahami secara mendalam [1-4]. Meskipun terdapat bukti yang melaporkan adanya tanda-tanda yang berkaitan dengan gempabumi swarm Matsushiro Jepang pada tahun 1965-1967 [5]. Kondisi atmosfer dan kajian mengenai tanda-tanda kejadian gempabumi secara langsung terhubung karena adanya fenomena lightning earthquake. Hal ini secara teratur dilaporkan pada kejadiankejadian gempabumi di Jepang $[5,6]$.

Tahun 2009, Astra [7] mengkaji tanda-tanda sebelum kejadian gempabumi dengan melihat penyimpangan medan mag- 
BMKG ShakeMap : Northern Sumatra, Indonesia

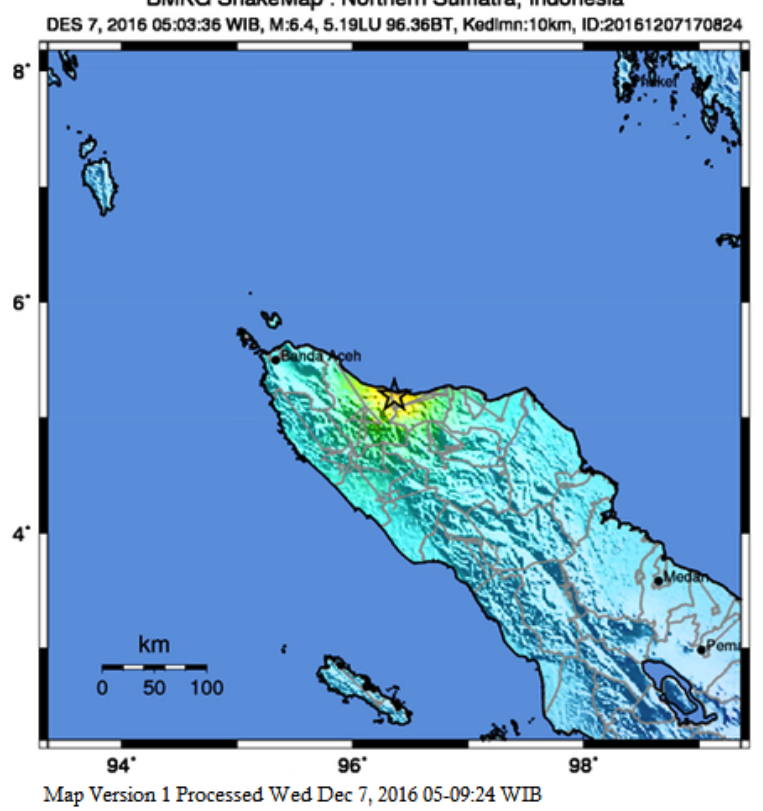

Gambar 1: Pusat gempabumi Pidie Jaya [9].

netik di atmosfer sebelum terjadinya gempabumi Yogyakarta tahun 2006. Dalam penelitiannya, diketahui bahwa sebelum terjadi gempabumi Yogyakarta 26 Mei 2006 terjadi penyimpangan medan magnetik pada $\mathrm{H}-4$ dari gempabumi yaitu 22 Mei 2006. Penyimpangan ditandai dengan terjadi penurunan jumlah kandungan elektron. Kepastian bahwa penyimpangan tersebut disebabkan oleh gempabumi didapat setelah dilakukan koreksi menggunakan Dst Index. Hasilnya, diketahui penyimpangan terjadi bukan karena gangguan magnetik di ionosfer. Hal ini dikarenakan proses interaksi lempeng bumi menghasilkan sebuah panas yang naik ke udara sehingga menyebabkan perubahan jumlah partikel elektron di atmosfer. Penelitian sebelumnya, Finkelstein dan Powell (1970) [8], menyebutkan sebelum gempabumi terjadi, batuan mengalami peningkatan stress dan ketika gempabumi terjadi batuan akan mengalami pelepasan energi. Pelepasan energi yang diikuti dengan pergeseran pada bidang lithosfer diketahui mengakibatkan naiknya polaritas listrik dengan frekuensi tinggi di hiposenter yang disebut dengan piezoelektrik.

Pada penelitian ini, proses panas yang naik keudara diterjemahkan sebagai proses evaporasi pada pembentukan awan. Pada proses evaporasi terjadi perpindahan panas di permukaan bumi sehingga terjadi penambahan uap air di udara yang kemudian membentuk awan. Sebagaimana diketahui bahwa aktivitas listrik udara sangat bergantung pada awan. Listrik udara merupakan sebuah peristiwa yang terjadi akibat adanya perbedaan muatan di dalam awan. Salah satu tipe listrik udara yang berkaitan langsung dengan permukaan bumi adalah listrik udara dari awan ke tanah (cloud to ground).

Berdasarkan latar belakang di atas, penelitian ini bertujuan untuk mengkaji tanda-tanda sebelum kejadian gempabumi dengan melihat korelasi antara sebuah kejadian gempabumi de- ngan aktivitas listrik udara sebelum gempabumi terjadi.

\section{METODOLOGI}

Penelitian ini terfokus pada kejadian gempabumi di daerah Pidie Jaya, Aceh. Kejadian gempabumi yang dimaksud adalah gempabumi Pidie Jaya seperti ditunjukan pada Gambar 1. Gempabumi yang terjadi pada tanggal 7 Desember 2016 pada pukul 05:03:36 WIB dengan kekuatan 6.4 S. Gempabumi berpusat di $18 \mathrm{~km}$ Timur Laut Kabupaten Pidie Jaya, Aceh. Data yang digunakan dalam menganalisis tanda-tanda sebelum terjadi gempabumi tersebut bersumber dari data aktivitas listrik udara pada tanggal 4 Desember 2016 sampai dengan tanggal 10 Desember 2016.

Data aktivitas listrik udara diperoleh dari hasil rekaman alat Ligthning Deterctor yang terpasang pada stasiun geofisika Mata Ie Banda Aceh. Data hasil rekaman merupakan data aktivitas listrik udara se-Aceh. Oleh karena itu, data diseleksi berdasarkan rentang wilayah daerah kejadian gempabumi yakni Pidie Jaya, Aceh. Rentang wilayah yang membentuk sebuah grid dengan batasan 4,85 LU-5,95 LU dan 95,90 BT-97,10 BT. Data aktivitas listrik udara selanjutnya diekstrak menjadi data aktivitas listrik udara per jam untuk kemudian diperoleh grafik aktivitas listrik udara per jam per hari.

Data lainnya yang digunakan sebagai pembanding dan validasi adalah data citra satelit Himawari 8 dan data curah hujan model GSMaP. Data citra satelit himawari8 disesuaikan dengan temporal data aktivitas listik udara yakni tanggal 4 s.d. 10 Desember 2016. Data curah hujan yang digunakan merupakan data model yang diperoleh dari citra Global Satellite Mapping Precipitation(GSMap). Kedua data, citra satelit Himawari8 dan GSMap juga diekstrak untuk diperoleh data per jam.

Pengolahan data menggunakan beberapa perangkat lunak seperti Lightning 2000, Microsoft Excel 2010, GRADs dan SATellite Animation and Interactive Diagnosis (SATAID). Data aktivitas listriku dara yang diperoleh dari alat Lightning Detector memiliki ektensi *.ldc, sehingga dilakukan konversi kedalam format *.csv menggunakan perangkat lunak Lightning 2000. Tidak berbeda dengan data aktivitas listrik udara, data citra satelit seperti citra himawari 8 dan data curah hujan model juga dilakukan konversi. Konversi dilakukan dengan perangkat SATAID dan GRADs untuk menghasilkan data suhu puncak awan per jam dan data curah hujan per hari. Proses selanjutnya, mengidentifikasi hubungan antara data aktivitas listrik udara dengan data curah hujan yang diperoleh dari model GSMaP. Identifikasi hubungan data dilakukan dengan melihat nilai koefisien korelasi (r) dengan menggunakan Persamaan (1). Proses analisis koefisien korelasi dan koefisien determinasi dilakukan menggunakan perangkat lunak Microsoft Excel 2010.

$$
r=\frac{n \sum X_{i} Y_{i}-\sum X_{i} \sum Y_{i}}{\sqrt{n \sum X_{i}^{2}-\left(\sum X_{i}\right)^{2}} \sqrt{n \sum Y_{i}^{2}-\left(\sum Y_{i}\right)^{2}}}
$$



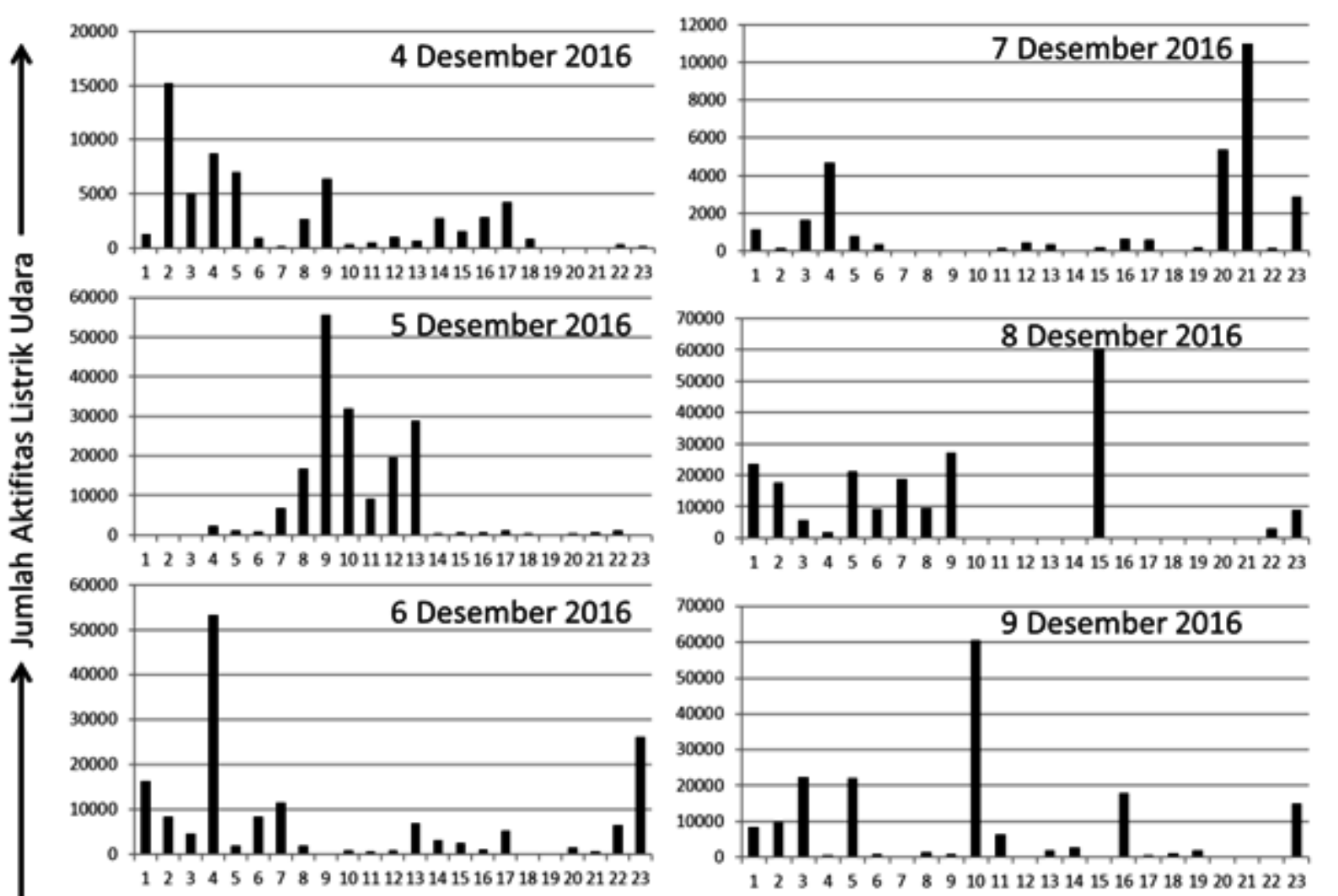

Waktu Kejadian Aktifitas Listrik Udara (WIB)

Gambar 2: Grafik aktivitas listrik udara/jam (Pengolahan data, 2017).

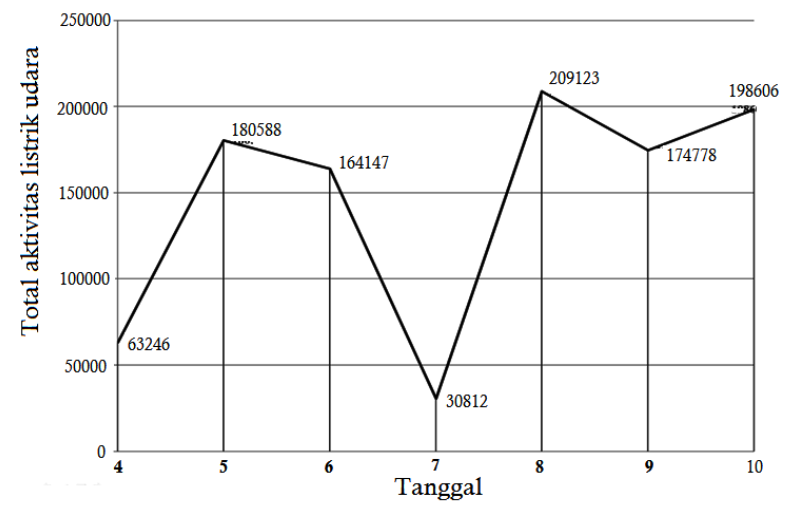

Gambar 3: Grafik total aktivitas listrik udara/hari (Pengolahan data, 2017).

Kepastian dalam menyimpulkan bahwa aktivitas listrik udara memberikan tanda-tanda sebelum terjadi gempabumi adalah dengan melakukan analisis korelasi dengan data curah hujan. Sebagai hipotesis awal, aktivitas listrik udara yang terjadi sebelum terjadi gempabumi disebabkan oleh awan konvektif yang tumbuh di sekitar area pusat gempabumi, namun tidak diikuti dengan hujan dengan intensitas sedang ataupun tinggi sebagaimana mestinya. Hipotesis ini di-

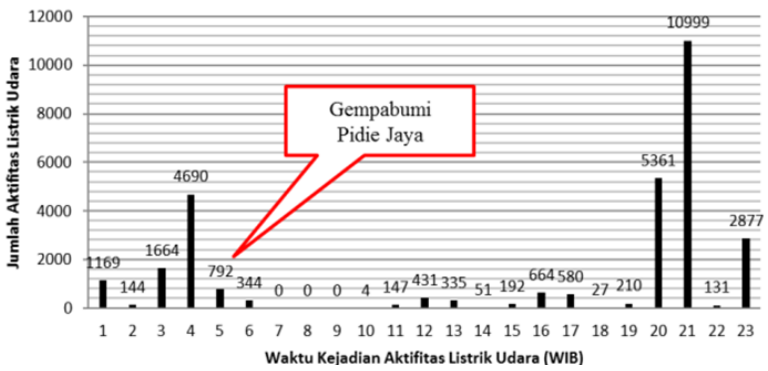

Gambar 4: Grafik total aktivitas listrik udara/jam (Pengolahan data, 2017).

maksudkan agar aktivitas petir yang terjadi dapat dikatakan sebagai tanda-tanda murni sebelum terjadinya gempabumi.

\section{HASIL DAN PEMBAHASAN}

\section{Data aktivitas listrik udara}

Analisis data aktivitas listrik udara berdasarkan grafik ak- 


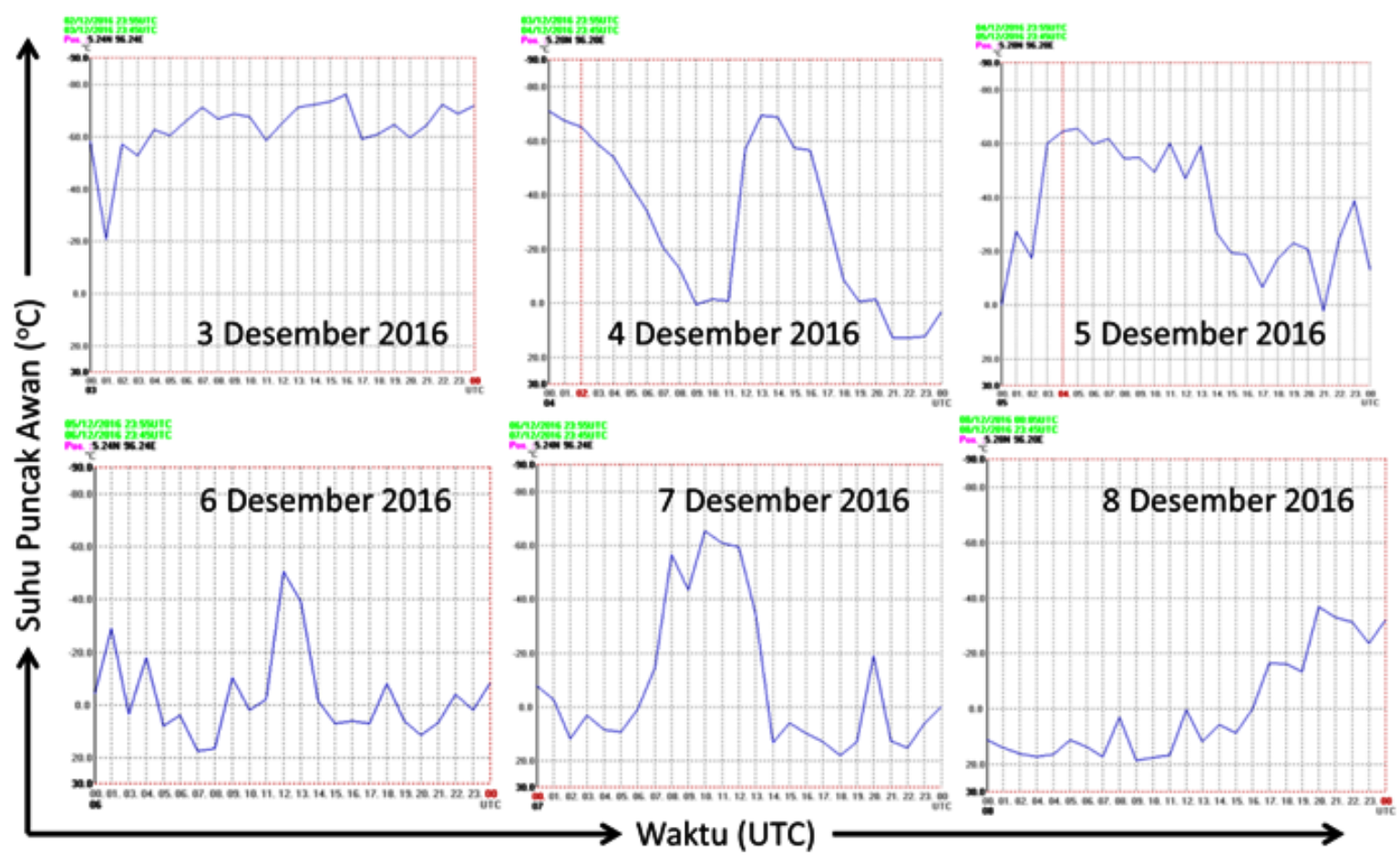

Gambar 5: Grafik suhu puncak awan/jam (Pengolahan data, 2017).

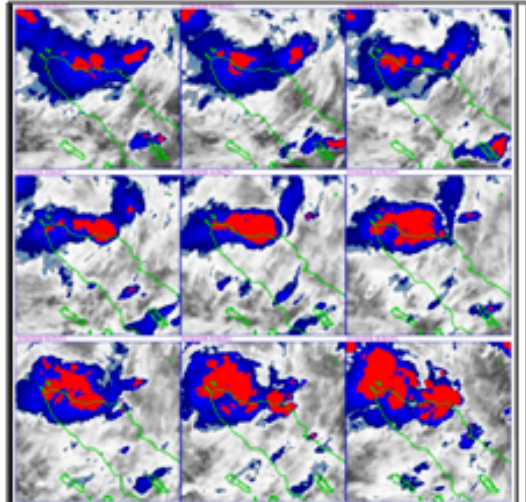

3 Desember 2016

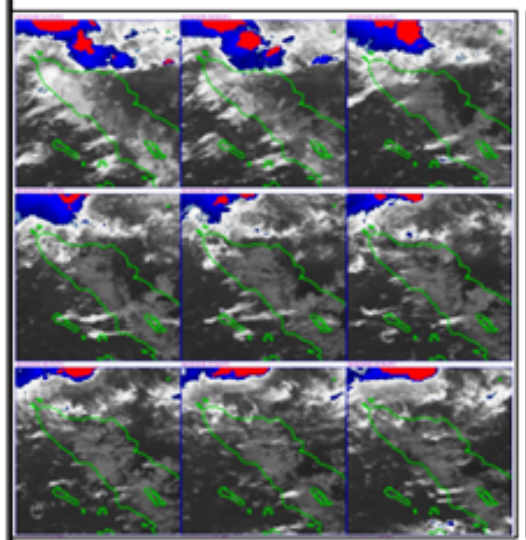

6 Desember 2016

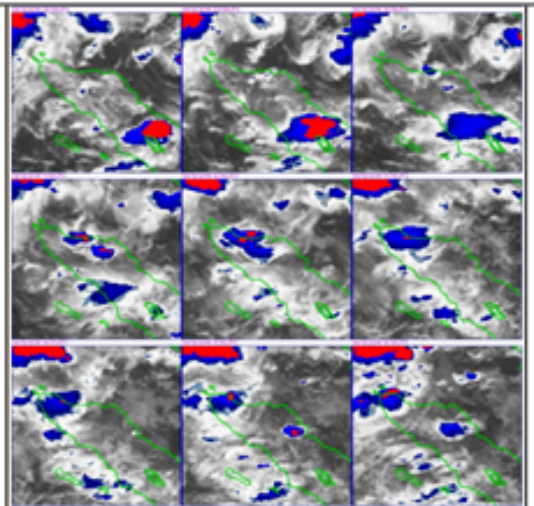

4 Desember 2016

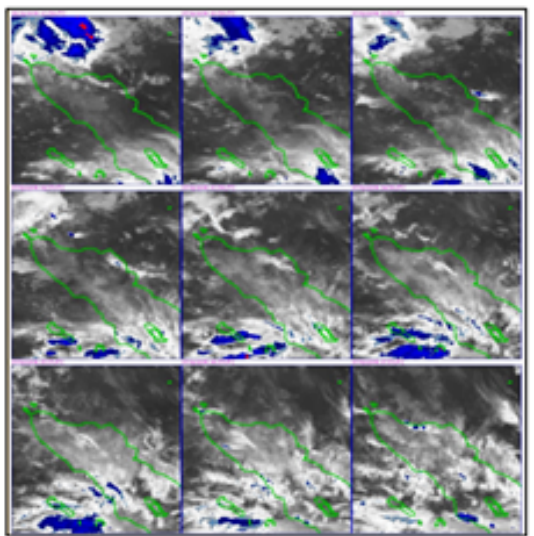

7 Desember 2016

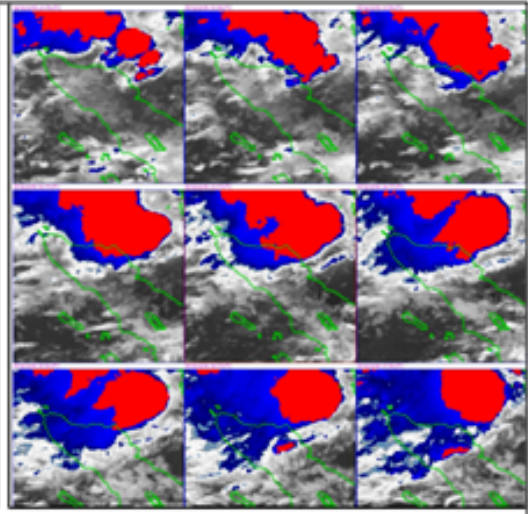

5 Desember 2016

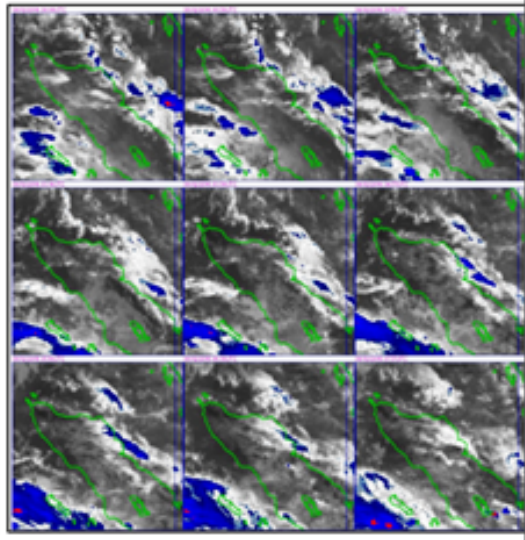

8 Desember 2016

Gambar 6: Data visual citra satelit Himawari 8 (Pengolahan data, 2017). 


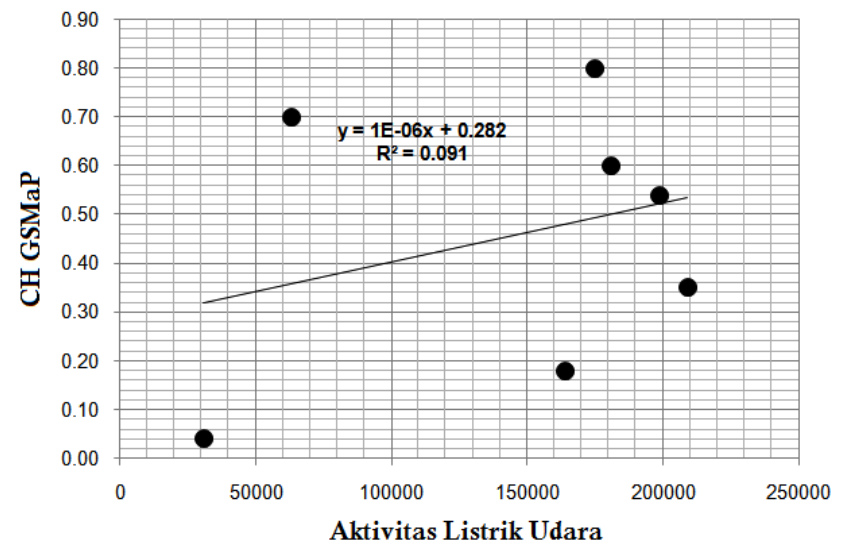

Gambar 7: Grafik korelasi aktivitas listrik udara dan $\mathrm{CH}$ GSMaP (Pengolahan data, 2017).

tivitas listrik udara/jam pada Gambar 2 diketahui adanya variasi jumlah aktivitas listrik udara. Selama periode tanggal 4 Desember 2016 sampai dengan 9 Desember 2016, data aktivitas tertinggi sebanyak 55.580 sambaran listrik udara, tepatnya pada tanggal 6 Desember 2016 Pukul 04:00:00 WIB. Aktivitas sambaran terendah terjadi pada tanggal 7 Desember 2016 sebanyak 4 sambaran listrik udara pada pukul 10:00:00 WIB.

Aktivitas listrik udara tertinggi dan terendah yang dihasilkan bersesuaian dengan tanggal sebelum dan saat kejadian Gempabumi Pidie Jaya. Analisis data aktivitas listrik udara dilanjutkan dengan pengolahan data aktivitas listrik udara per hari. Hasil data analisis diperoleh adanya peningkatan jumlah aktivitas listrik udara sejak $\mathrm{H}-2$ sebelum gempabumi terjadi, seperti yang ditunjukan pada Gambar 3 .

Pada penelitian lain, aktivitas listrik udara cenderung terdistribusi di sekitar pusat gempabumi dan mengalami kenaikan secara signifikan 17-19 hari sebelum gempabumi darat dengan kedalaman dangkal $(\mathrm{D} \leq 20 \mathrm{Km})$ dengan $\mathrm{M} \geq 6,0$ [10]. Peningkatan jumlah aktivitas listrik udara yang terjadi pada H-2 menunjukan adanya penurunan aktivitas listrik udara saat terjadi gempabumi sebanyak 133.335 sambaran. Jika ditinjau kembali pada aktivitas per jam (pada tanggal 7), peningkatan aktivitas terjadi sejam sebelum terjadinya kejadian gempabumi (Gambar 4) sebanyak 3.898 sambaran.

Hasil pengolahan terhadap data aktivitas listrik udara yang menunjukan adanya peningkatan $\mathrm{H}-2$ sebelum hari kejadian gempabumi didukung dengan data citra satelit Himawari 8. Seperti yang ditunjukan pada Gambar 5, grafik suhu puncak awan /jam juga menunjukkan adanya peningkatan pertumbuhan awan pada tanggal 5 Desember 2016.

Hal ini juga terlihat jelas, sebagaimana diperlihatkan pada
Gambar 6, visualisasi citra satelit Himawari 8 menunjukkan distribusi awan konvektif dengan mengalami peningkatan sejak tanggal 3 Desember 2016 hingga puncak intensitas tinggi pada tanggal 5 Desember 2016. Selanjutnya, distribusi awan konvektif berangsur-angsur menurun pada tanggal 6 Desember 2010 hingga tanggal 8 Desember 2016.

Berdasarkan hasil ini, diperoleh dugaan bahwa proses terjadinya gempabumi dapat mempengaruhi aktivitas listrik di udara. Hal ini ditandai dengan peningkatan aktivitas listrik udara sehari bahkan sejam sebelum kejadian gempabumi Pidie Jaya.

\section{Analisis koefisien korelasi}

Analisis korelasi yang dilakukan antara dua variabel yakni aktivitas listrik udara dan curah hujan menghasilkan nilai koefisien sebesar 0,3 seperti pada Gambar 7. Koefisien korelasi diartikan bahwa hubungan linier antara kedua variable sangat lemah. Dengan kata lain, aktivitas listrik udara yang terjadi tidak diikuti oleh kejadian hujan dengan intensitas sedang atau pun tinggi. Hal ini bersesuaian dengan hipotesis awal penelitian, aktivitas listrik udara yang terjadi sebelum terjadi gempabumi disebabkan oleh awan konvektif yang tumbuh di sekitar area pusat gempabumi, namun tidak diikuti dengan hujan dengan intensitas sedang ataupun tinggi. Dengan demikian hasil analisis koefisien korelasi menunjukan bahwa aktivitas listrik udara yang meningkat bersesuaian dan dapat dianggap sebagai tanda-tanda (prekursor) kejadian gempabumi Pidie Jaya.

\section{SIMPULAN}

Penelitian mengenai tanda-tanda sebelum terjadinya gempabumi menjadi topik kajian yang telah lama dilakukan. Gempabumi merupakan fenomena yang terjadi akibat interaksi lempeng tektonik dipercaya juga dapat membangkitkan fenomena lain seperti gangguan pada atmosfer. Pada penelitian ini, disimpulkan bahwa aktivitas gempabumi yang terjadi memicu peningkatan aktivitas listrik udara $\mathrm{H}-2$ sebelum terjadinya gempabumi. Peningkatan aktivitas listrik udara yang terjadi diketahui murni menggambarkan tanda-tanda sebelum gempabumi. Hal ini didasari pada hasil analisis koefisien korelasi yang menunjukan hubungan sangat lemah antara peningkatan aktivitas listrik udara dengan curah hujan. Sebagaimana umumnya kejadian listrik udara yang diakibatkan awan-awan konvektif dengan diikuti oleh aktivitas hujan dengan intensitas sedang hingga tinggi. 
[1] U. Nitsan, "Electromagnetic emissions accompanying fracture ofquartz bearing rocks"”, Geophys. Res. Lett., vol. 4, pp. 333337, 1997.

[2] T. Ogawa, K. Oike, T. Miura, "Electromagnetic radiations fromrocks", J. Geophys. Res., vol. 90, pp. 6245-6249, 1985.

[3] Y. Enomoto, H. Hashimoto, "Transient electrical activity accompanying rock rupture under indentation loading"', Tectonophysics, vol. 211, pp. 337, 1992.

[4] Y. Enomoto, H. Hashimoto, "Anomalous electric signal detectedbefore recent Earthquakes in Japan near Tsukuba", Terra. Sci. Pub. Co., Tokyo, pp. 261-270, 1994.

[5] Y. Yasui, "A summary of studies on luminousphenomena accompanied with earthquakes", Mem.KakiokaMagn. Observ., vol. 15, pp. 127-138, 1973.

[6] J.S. Derr, "Earthquake lights: a review of observations and present theories", Bull. Seism. Soc. Am., vol. 63, pp. 2177 -
2187, 1973.

[7] I.M.A. Astra, "Analisa Vertical Total Electron Content Di Ionosfer Daerah Jawa Dan Sekitarnya Yang Berasosiasi Dengan Gempabumi Yogyakarta 26 Mei 2006 Utc"', Tugas Akhir, Akademi Meteorologi dan Geofisika, Tangerang 2009.

[8] D. Finkelstein, and J.R. Powell, "Earthquake lightning", Nature, vol. 228, pp. 759-760, 1970.

[9] http://inatews.bmkg.go.id/shakemap/ 20161207170824/ download/ intensity.jpg

[10] X. Jin, Z. Chen, Q. Ma, Y. Li and J. Pu, "The Correlations between the Lightning Density Distribution of Sichuan Province and the Seismic Area", International Journal of Geosciences, vol. 4, pp. 380-386, 2013 [http://dx.doi.org/10.4236/ijg.2013.42036]. 